\title{
Effect of Feeding Longan Dimocarpus longan Residue before Estrus Synchronization on Reproductive Performance in Ewes
}

\author{
Tossapol Moonmanee ${ }^{1,2, *}$, Saowaluck Yammuen-art ${ }^{1}$, Mintra Seel-audom ${ }^{1}$, Yongyouth Srivichai ${ }^{1,2}$ \\ ${ }^{1}$ Department of Animal and Aquatic Science, Faculty of Agriculture, Chiang Mai University, Chiang Mai 50200, Thailand \\ ${ }^{2}$ Goat and Sheep Unit, Department of Animal and Aquatic Science, Faculty of Agriculture, Chiang Mai University, \\ Chiang Mai 50200, Thailand \\ *Corresponding author: tossapol.m@cmu.ac.th
}

Received May 25, 2015; Revised June 29, 2015; Accepted July 03, 2015

\begin{abstract}
To evaluate the effect of feeding longan residue (longan fruit; grade C) before estrus synchronization on reproductive performance in sheep, sixteen ewes observed in estrus were selected and randomly assigned to 2 groups: control group $(n=8)$ received the maintenance diet whiles the longan-supplemented group $(n=8)$ received the maintenance diet plus $300 \mathrm{~g} \mathrm{DM} /$ head/day of longan fruit for 17 days. Blood concentrations of glucose, insulin, progesterone $\left(\mathrm{P}_{4}\right)$, and estradiol $\left(\mathrm{E}_{2}\right)$, and follicular population were recorded. After the nutritional treatments, all ewes were synchronized for estrus with controlled intravaginal drug release (CIDR) devices and $400 \mathrm{IU}$ pregnant mare serum gonadotropin. Ewes exhibiting estrus were subjected to assisted natural mating by rams. Ewes fed longan-supplemented diet had greater feed intake than ewes fed the control diet. Glucose concentrations were higher in longan-supplemented than those in control ewes on days 7, 14, and 17. Insulin concentrations were only higher in longan-supplemented group than those in control group on day 17. The longan-supplemented ewes had higher $\mathrm{E}_{2}$ concentrations than non-supplemented ewes on days 14 and 17. On days 14 and 17, numbers of total follicles had significantly greater in longan-supplemented ewes compared with control ewes. Estrous response and conception rate were not different between control and treatment ewes. It was concluded that the 17 days of dietary supplementation stimulate ovary (total follicles) ready to respond to the synchronization of estrus. However, dietary supplementation with longan fruit in ewes prior to the start of the estrus synchronization did not enhance reproductive performance.
\end{abstract}

Keywords: longan fruit, estrus synchronization, reproductive performance, Ewes

Cite This Article: Tossapol Moonmanee, Saowaluck Yammuen-art, Mintra Seel-audom, and Yongyouth Srivichai, "Effect of Feeding Longan Dimocarpus longan Residue before Estrus Synchronization on Reproductive Performance in Ewes.” World Journal of Agricultural Research, vol. 3, no. 3 (2015): 113-118. doi: 10.12691/wjar-3-3-4.

\section{Introduction}

There is an increased demand for animal products in Thailand and other developing countries, thereby increasing the demand for adequate and inexpensive animal feed. Scientists have developed feeding strategies that guarantee the sustainability of livestock production systems based on local feed sources [1]. Several reports have shown that tropical fruit by-products can be used as animal feed to replace cereal-based concentrates without negatively affecting animal production performance [1], such as mango residues in sheep [2], tomato and cucumber waste fruits in dairy goats [3], and longan residues in cattle [4]. Moreover, many of these by-products are largely wasted or unused [5].

Longan (Dimocarpus longan Lour.) is a tropical fruit tree that is generally grown in the northern part of Thailand, particularly in the upper provinces of the northern region [6]. According to the botanical description, the Dimocarpus longan (taxonomic serial no.: 506072) is an evergreen tree that can grow up to $20 \mathrm{~m}$ in height. Flowers are small and yellowish brown that cymules 3 to 5 flowered and usually only the central flower developed into fruit [7]. The fruit rind is thin but tough and leathery and changes color from greenish yellow to yellowish brow with indicating maturity. Normally, only one seed is appearance in each fruit [7]. In 2012, Thailand exported more than 600,000 tons of fresh and processed longan, with a total value exceeding US\$650 million [8]. Fresh longan contains $81 \%$ water, $17 \%$ carbohydrate and $1 \%$ protein [8], and provides an assortment of nutrients such as glucose, sucrose, fructose and vitamins C, B1 and B2 [9]. Moreover, the Thai farmers have establishes grading of longan fruits into Grades A, B, and C. The Grade A fruits consists of 55-75 fruits/kg (14-18 g/fruit), Grade B consists of 76-80 fruits/kg (12.5-13.5 g/fruit), and Grad C consists of more than 80 fruits $/ \mathrm{kg}$ which encompasses most small-fruited (low quality) seedling types $[7,10]$. In 
longan production system, a previous study indicated that longan residues include leaves, branch, fruit branch, wilted or rotten fruits, small-fruited grading type (Grade C), fruit peel and seed [4]. For the chemical composition, longan fruit (Grade C) contains 36.1\% dry matter, 8.0\% crude protein, $6.1 \%$ crude fiber, and $4,213 \mathrm{kcal} / \mathrm{g}$ of gross energy [4]. Moreover, a recent study concluded that the nutritive value and volume of longan fruit (Grade C) were high enough to be used as ruminant feed [4].

Nutritional condition has a strong influence on the activity of the hypothalamo-pituitary-gonadal axis in mammals [11,12]. In females of small ruminant species, such as sheep and goat, nutritional supplementation stimulates development of the small follicle population $[13,14]$, growth rate and size of the ovulatory follicle [12], ovulation rate $[13,15]$, and litter size [16]. On the basis of the previous observations, short-term feeding of highenergy diets to cyclic ewes increased blood insulin and glucose concentrations and also affected the follicular environment [17]. Moreover, previous studies demonstrated that short-term supplementation before luteolysis significantly affected folliculogenesis in the follicular phase [15] but not in the luteal phase [17]. Although follicular growth continuum is controlled primarily by gonadotropins and locally produced growth factors, a number of environmental factors, such as nutrition, can influence follicular development and oocyte quality, and hence fertility [12,18,19].

The advantages of using agricultural by-products in livestock feeding are not only to minimize environmental pollution, but also to reduce dependency on highly expensive ingredients such as grains and roughages [20]. A lot of work has been done on the potential uses of tropical fruit by-products in ruminant diets. However, very little is known about the effect of longan residues in the production of ruminants. Moreover, the effect of feeding longan residues in the reproductive performance of sheep is unknown. Based on the chemical compositions of longan residue, we believe that use of longan fruit containing high gross energy can enhance folliculogenesis and subsequent reproduction in ewes, as indicated by increase in the characteristics of estrus. We hypothesized that dietary supplementation with longan residue (longan fruit) before estrus synchronization can be stimulated the follicular population and enhanced reproductive performance in sheep. Therefore, our aim was to determine effect of feeding longan residue (longan fruit; Grade C) before estrus synchronization on blood concentrations of glucose, sex hormones, and reproductive performance in ewes.

\section{Materials and Methods}

This experiment was conducted at goat and sheep farm, Department of Animal and Aquatic Science, Faculty of Agriculture, Chiang Mai University situated at longitude $98^{\circ} 55^{\prime} 54.3^{\prime \prime} \mathrm{E}$, latitude $18^{\circ} 45^{\prime} 40.3^{\prime \prime} \mathrm{N}$ and an altitude of $312 \mathrm{~m}$ above sea level. The climate was tropical with distinct differences between dry (October-April) and wet (May-September). Before experiments, all ewes were determined to ensure an absence of reproductive problems, and all animals remained healthy throughout the study.

\subsection{Animals and Treatments}

Estrous cycle of mature crossbred ewes (Merino to Thai native; 12-24 mo of age; $29.1 \mathrm{~kg}$ of $\mathrm{BW}$ ) were synchronized by treating with controlled intravaginal drug release (CIDR) devices (Eazi-Breed CIDR, $0.3 \mathrm{~g}$ progesterone; Pfizer Animal Health, New Zealand) for 12 days. Estrous behavior was monitored in the presence of two vasectomized rams at 08:00 and 18:00 for 5 days following removal of CIDR devices. Commencement of estrus was defined as the time when the ewe first stood to be mounted by the ram [21]. Day of first detection of estrous behavior was designated as day 0 of the estrous cycle. Ewes that displayed estrous behavior were selected and randomly allotted control $(n=8)$ or longansupplemented $(n=8)$ groups. Ewes were placed in individual pens (1.5 m wide by $2.2 \mathrm{~m}$ long) in separate groups according to the type of supplement and preoffered a maintenance diet for 7 days (adaptation period). During the experimental period, control ewes were fed pangola hay ad libitum and concentrate at $1.5 \%$ of $\mathrm{BW}$ (maintenance diet) throughout the nutritional supplementation. The longan-supplemented ewes received additionally $300 \mathrm{~g} \mathrm{DM}$ /head/day of longan fruit (Grade C) for 17 days starting at day 0 to day 17 . All ewes received two equal allotments of feed at $0900 \mathrm{~h}$ and $1700 \mathrm{~h}$ and the refusals were removed and weighed each time. Individual feed intake was used to calculate individual dry matter (DM) intake. Samples of offered diets were collated once a week and analyzed for dry matter (DM), crude protein (CP), ether extract (EE), crude fiber (CF), and ash [22]. Gross energy (GE) was measured using a bomb calorimeter [23]. Ewes in both groups had ad libitum access to water and mineral block. Animals were weighed at the beginning and the end of the supplement. The ingredients and chemical composition of the diets are reported in Table 1.

Table 1. Ingredients and chemical composition of concentrate mixture, pangola hay, and longan fruit (Grade C) of experimental diets

\begin{tabular}{lccc}
\hline \multicolumn{1}{c}{ Ingredients } & Concentrate & $\begin{array}{c}\text { Pangola } \\
\text { hay }\end{array}$ & $\begin{array}{c}\text { Longan } \\
\text { fruit }\end{array}$ \\
\hline Incorporation level (\%) & & & - \\
$\quad$ Corn meal & 61.0 & - & - \\
Soybean meal & 25.0 & - & - \\
Rice bran & 12.0 & - & - \\
Salt & 1.0 & - & - \\
Dicalcium phosphate & 1.0 & - & 30.86 \\
Chemical composition & & & 7.46 \\
Dry matter (DM, \%) & 89.02 & 91.71 & 13.71 \\
Crude protein (\% DM) & 14.60 & 6.40 & 1.79 \\
Crude fiber (\% DM) & 5.51 & 33.73 & 4.02 \\
Ether extract (\% DM) & 6.15 & 1.94 & $4,252.76$ \\
Ash (\% DM) & 7.32 & 12.74 & \\
Gross energy (cal/g) & $4,475.00$ & $4,059.00$ & -
\end{tabular}

After the nutritional treatments, all ewes were synchronized for estrus with CIDR devices for 12 days and 400 IU pregnant mare serum gonadotropin (PMSG; Folligon, Intervet, Boxmeer, Holland) was injected upon removal of the CIDR devices [21]. After withdrawal of CIDR devices, the overt sings of estrus were detected twice daily for a 5-day period with the aid of teaser rams. 
Ewes were considered to be in estrus when mounted by the teaser rams and then were subjected to assisted natural mating by desired fertile rams [24].

\subsection{Ultrasonographic Observation}

Transrectal ovarian ultrasonography was performed with a 7.5 MHz linear-array transducer (TOSHIBA JustVision 2000, Japan). Ultrasound examination of ovarian follicles was conducted on days $0,7,14$, and 17 of the feeding period. At each scan, the size and number of follicles were measured and recorded on follicular maps, which allowed identification for subsequent analyses. The visible follicles were classified by size as follows: small, 2 to $3 \mathrm{~mm}$; medium, $>3$ to $<5 \mathrm{~mm}$; large, $\geq 5 \mathrm{~mm}$ [24]. Pregnancy was diagnosed by ultrasound scanning of the uterine contents 35 days following mating [25].

\subsection{Reproductive Measurements}

After withdrawal of CIDR devices, standing estrus was detected by visual observation during a 5-day period with the aid of teaser rams. The onset of estrus was defined as the time when the ewe first stood to be mounted by the ram. Duration of estrus was defined as the interval between the onset of estrus and the end of estrus. The end of estrus was considered to be the time when the ewe did not accept the ram [21]. On the basis of reproductive measurements, estrous response (number of ewes exhibiting estrus/total number of synchronized ewes $\mathrm{x}$ 100; \%), time to onset and end of estrus (h), duration of estrus (h), and conception rate (number of ewes conceiving on day 35/total number of exposed ewes $\mathrm{x}$ 100; \%) were calculated for each treatment groups [25].

\subsection{Blood Sampling}

Jugular blood samples $(10 \mathrm{ml})$ were collected into venipuncture prior to each ultrasound scanning (on days 0 , 7, 14, and 17 of the supplemental period). Each blood sample was divided into two equal parts for analysis of concentrations of glucose and hormones. First one was placed into fluoride-containing tubes (sodium fluoride/ $\mathrm{K}_{3}$ EDTA, Greiner Bio-one VACUETTE; North America) while the second was placed into sterile tubes and was allowed to coagulated at room temperature. After centrifugation at $3000 \mathrm{rpm}$ for $15 \mathrm{~min}$, plasma or serum samples were harvested and stored at $-20^{\circ} \mathrm{C}$ until glucose and hormonal analyses [26].

\subsection{Glucose and Hormonal Analyses}

Plasma glucose concentrations were analysed by the hexokinase method [27]. Plasma insulin concentrations were determined by electrochemiluminescence immunoassay using insulin kit according to the instructions provided by the manufacturer (Cobas ${ }^{\circledR}$, Roche Diagnostics, Mannheim, Germany). Serum progesterone $\left(\mathrm{P}_{4}\right)$ and estradiol $\left(\mathrm{E}_{2}\right)$ concentrations were measured in duplicate by competitive enzyme-linked immunosorbent assay (competitive ELISA; adapted from Brown et al. [28]). Using duplicate $10 \mu \mathrm{l}$ aliquots, the assay sensitivities were $0.203 \mathrm{ng} / \mathrm{ml}$ for $\mathrm{P}_{4}$ and $0.040 \mathrm{ng} / \mathrm{ml}$ for $E_{2}$. Inter-assay coefficient of variation was $11.3 \%$ for $\mathrm{P}_{4}$ and $13.8 \%$ for $\mathrm{E}_{2}$. Intra-assay of coefficient of variation was $7.1 \%$ for $\mathrm{P}_{4}$ and $8.1 \%$ for $\mathrm{E}_{2}$.

\subsection{Statistical Analyses}

Data are presented as mean \pm SEM. Body weight (BW), DMI, numbers and sizes of ovarian follicles, interval to onset of estrus, and duration of estrus were analyzed with ANOVA with the general linear model (GLM) procedure of SAS (SAS Institute, Cary, NC, USA). Differences between means were evaluated by Student $t$ test [29]. Plasma glucose and insulin, serum $\mathrm{P}_{4}$, and $\mathrm{E}_{2}$ concentrations were analyzed with a nested analysis of variance with treatment, animal (treatment), and day included in the model, and differences between specific means were evaluated by least significant difference [30]. Estrous response and conception rate were analyzed by chi-square analysis [29]. Differences with $P \leq 0.05$ were considered significant, and those with $0.05<P<0.10$ were considered a tendency [31].

\section{Results}

\subsection{Body Weight and DM Intake}

The body weight and feed intake of control and longansupplemented ewes are demonstrated in Table 2. The live weights of ewes in control and longan-supplemented groups were similar both at the beginning and the end of the supplement $(P>0.05)$. There were no differences $(P>0.05)$ among treatment groups for the DM intakes of pangola hay and concentrate. However, ewes fed longansupplemented diet had greater $(P<0.05)$ total DM intake than ewes fed the control diet.

\subsection{Plasma Glucose and Insulin Concentrations}

Plasma glucose and insulin concentrations of control and longan-supplemented ewes are illustrated in Figure 1. No interactions between treatment and day relative to feeding on plasma concentrations of glucose and insulin were observed. On day 0, plasma glucose concentration did not differ $(P>0.05)$ in the control and longansupplemented ewes. Nevertheless, glucose concentrations were higher in longan-supplemented than those in control ewes on days 7, 14, and 17 of the nutritional period (Figure 1A).

Table 2. Means ( \pm SEM) of body weights and voluntary feed intake of ewes fed a control diet or a diet containing longan fruit (Grade C)

\begin{tabular}{|c|c|c|}
\hline & Control group & $\begin{array}{c}\text { Longan- } \\
\text { supplemented group }\end{array}$ \\
\hline Initial BW (kg) & $28.8 \pm 0.37$ & $29.9 \pm 0.30$ \\
\hline Final BW (kg) & $29.5 \pm 0.40$ & $30.8 \pm 0.34$ \\
\hline \multicolumn{3}{|l|}{ Feed intake (g DM/d) } \\
\hline Pangola hay & $747.3 \pm 14.91$ & $740.6 \pm 18.73$ \\
\hline Concentrate & $348.3 \pm 10.35$ & $346.2 \pm 13.38$ \\
\hline Longan fruit & - & $120.1 \pm 1.80$ \\
\hline Total feed intake & $1,095.5 \pm 20.87^{\mathrm{b}}$ & $1,206.9 \pm 23.20^{\mathrm{a}}$ \\
\hline \multicolumn{3}{|c|}{$\begin{array}{l}\text { Abbreviations: } \mathrm{BW} \text {, body weight; } \mathrm{DM} \text {, dry matter } \\
\text { Note: Means with different superscript letters }\left({ }^{\mathrm{a}, \mathrm{b}}\right) \text { within the same row } \\
\text { are different }(P<0.05) \text { among control and longan-supplemented groups. } \\
\text { Figure } 1 \mathrm{~B} \text { illustrated that insulin concentrations were } \\
\text { only higher }(P<0.05) \text { in longan-supplemented group than } \\
\text { those in control group on day } 17 \text { of the nutritional period. }\end{array}$} \\
\hline
\end{tabular}




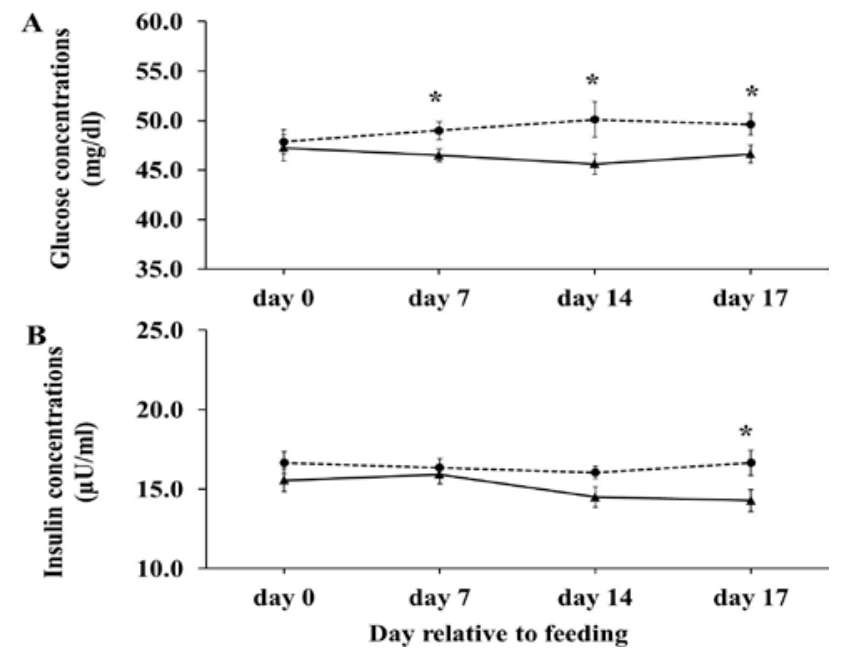

Figure 1. Means $( \pm$ SEM) concentrations of glucose (A) and insulin (B) in ewes that received control diet (triangles; solid line) and in ewes fed longan-supplemented diet (circles; dotted line) from day 0 to day 17 of the nutritional period. Asterisks denote significant $(*, \quad P<0.05)$ differences between control and longan-supplemented groups.

\subsection{Serum $\mathrm{P}_{4}$ and $\mathrm{E}_{2}$ Concentrations}

Data for serum concentrations of $\mathrm{P}_{4}$ and $\mathrm{E}_{2}$ of control and longan-supplemented ewes are shown (Figure 2). No interactions between treatment and day relative to feeding on serum concentrations of $\mathrm{P}_{4}$ and $\mathrm{E}_{2}$ were observed. The concentrations of $\mathrm{P}_{4}$ did not differ $(P>0.05)$ between treatment groups throughout the feeding period (Figure 2A). In control and longan-supplemented groups, the concentrations of $\mathrm{P}_{4}$ on day 7 were higher than those on days 0,14 , and 17 of the feeding period (Figure 2A).

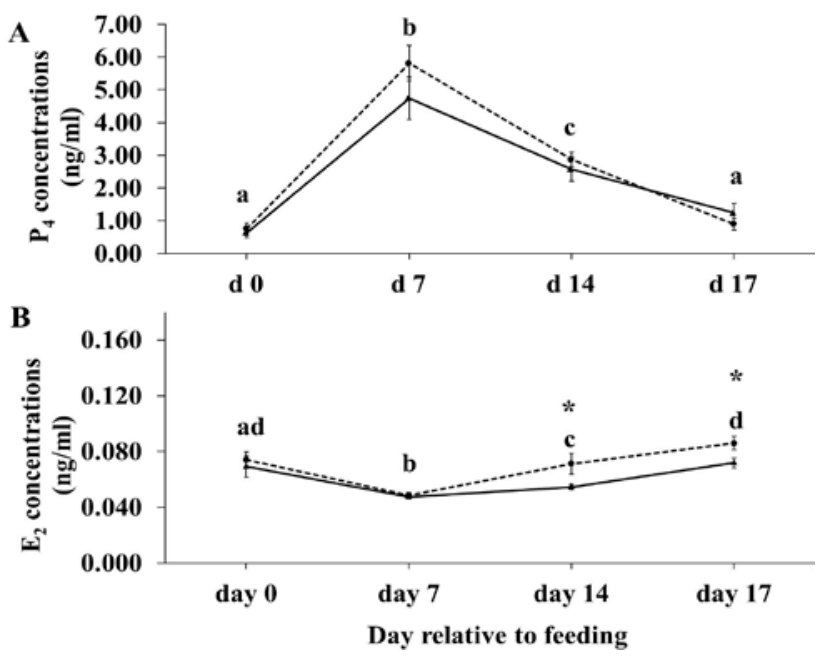

Figure 2. Means $\left( \pm\right.$ SEM) concentrations of $P_{4}(A)$ and $E_{2}(B)$ in ewes that received control diet (triangles; solid line) and in ewes fed longansupplemented diet (circles; dotted line) from day 0 to day 17 of the nutritional period. Asterisks denote significant $(*, P<0.05)$ differences between control and longan-supplemented groups. Means with different superscript letters $\left({ }^{\mathrm{a}, \mathrm{b}, \mathrm{c}}\right)$ are different $(P<0.05)$ among day relative to feeding. Abbreviations: $\mathrm{E}_{2}$, estradiol; $\mathrm{P}_{4}$, progesterone

No interactions between treatment and day relative to feeding on serum concentrations of $E_{2}$ were observed. The longan-supplemented ewes had higher $(P<0.05) \quad \mathrm{E}_{2}$ concentrations than non-supplemented ewes on days 14 and 17 of nutritional supplementation (Figure 2B). In all ewes, the concentrations of $E_{2}$ on day 7 were lower
$(P>0.05)$ than those on days 0,14 , and 17 of the feeding period (Figure 2B).

\subsection{Ovarian Follicular Population}

In Figure 3, average numbers of small, medium, large follicles as well as total follicles for each time of determination are characterized. No interactions between treatment and day relative to feeding on numbers of follicles were observed. The average numbers of smallsized follicles were similar $(P>0.05)$ for control and longan-supplemented groups throughout the feeding period (Figure 3A). The mean numbers of small-sized follicles were increased on day 7 and then decreased significantly on days 14 and 17 of the feeding period (Figure 3A).

No statistically significant difference was determined between control and longan-supplemented ewes in evaluation of the average numbers of medium-sized follicles $(P>0.05$; Figure $3 \mathrm{~B})$. In all ewes, the average numbers of medium-sized follicles on day 0 were fewer $(P<0.05)$ than those on days 7,14 , and 17 of the feeding period (Figure 3B).

For average numbers of large-sized follicles, there were no significant differences between control and longansupplemented ewes on days 0 and 7 ( $P>0.05)$; however, numbers of large-sized follicles in longan-supplemented ewes were greater $(P<0.01)$ than those in control ewes on days 14 and 17 of the treatment period (Figure 3C). In all ewes, the average numbers of medium-sized follicles on day 17 were greater $(P<0.05)$ than those on days 0,7 , and 14 of the feeding period (Figure $3 \mathrm{C}$ ).

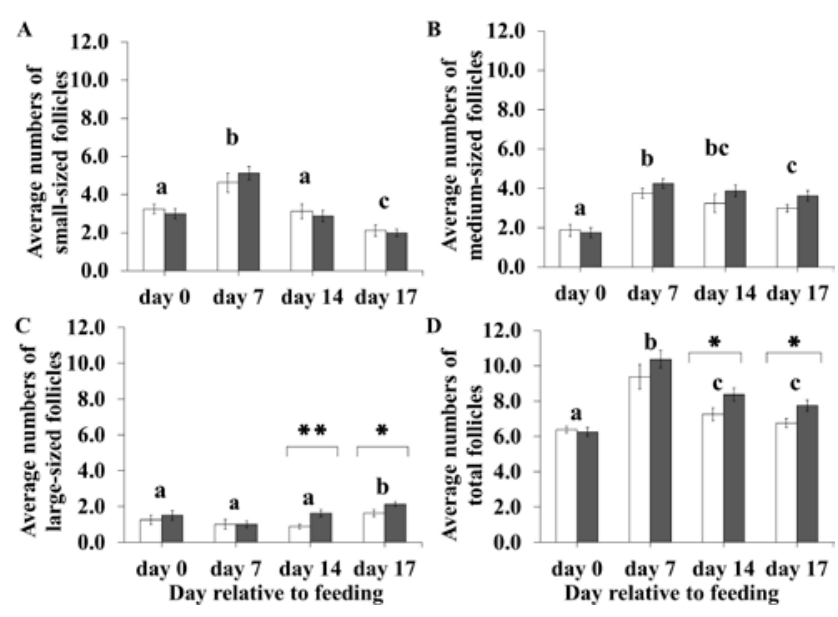

Figure 3. Means ( \pm SEM) numbers of small-sized (A), medium-sized (B), large-sized (C), and total follicles (D) in ewes that received control diet (open bars) and in ewes fed longan-supplemented diet (solid bars) from day 0 to day 17 of the nutritional period. Asterisks denote significant $(*, P<0.05)$ and highly significant $(* *, P<0.01)$ differences between control and longan-supplemented groups. Means with different superscript letters $\left({ }^{\mathrm{a}, \mathrm{b}, \mathrm{c}}\right)$ are different $(P<0.05)$ among day relative to feeding

In addition, there were no significant differences $(P>0.05)$ between control and longan-supplemented ewes in the mean numbers of total follicles on days 0 and 7 of the feeding period (Figure 3D). At initiation of the synchronization of estrus, average numbers of total follicles had significantly greater $(P>0.05)$ in longansupplemented ewes compared with control ewes as illustrated in Figure 3D. In all ewes, mean numbers of 
large-sized follicles on day 0 were lower than those on days 7, 14, and 17 (Figure 3D).

\subsection{Estrous Response and Reproductive Performance}

There was a tendency $(P=0.06)$ for time to onset of estrus to be shorter in longan-supplemented ewes than in control ewes (Table 3). Duration of estrous period in longan-supplemented ewes tended to be longer $(P=0.07)$ than that in control ewes. However, time to end of estrus was not different $(P>0.05)$ between control and treatment ewes (Table 3). No significant difference $(P>0.05)$ in the result for conception rate was determined between control and longan-supplemented groups (Table 3).

Table 3. The effects of feeding longan fruit before estrus synchronization on estrous response, times of the onset and end of estrus, and duration of estrous period

\begin{tabular}{|c|c|c|}
\hline & $\begin{array}{c}\text { Control } \\
\text { group }\end{array}$ & $\begin{array}{c}\text { Longan- } \\
\text { supplemented group }\end{array}$ \\
\hline Ewes (n) & 8 & 8 \\
\hline Estrous response (\%) & $75.0(6 / 8)$ & $87.5(7 / 8)$ \\
\hline $\begin{array}{l}\text { Onset of estrus (hour from CIDR } \\
\text { removal) }\end{array}$ & $42.7 \pm 3.4^{\mathrm{a}}$ & $33.1 \pm 3.1^{b}$ \\
\hline $\begin{array}{l}\text { End of estrus (hour from CIDR } \\
\text { removal) }\end{array}$ & $71.1 \pm 3.9$ & $70.7 \pm 7.6$ \\
\hline Duration of estrus (h) & $29.0 \pm 2.2^{\mathrm{a}}$ & $39.1 \pm 4.4^{b}$ \\
\hline Conception rate (\%) & $66.7(4 / 6)$ & $71.4(5 / 7)$ \\
\hline
\end{tabular}

Abbreviation: CIDR, controlled intravaginal drug release devices.

Note: Means with different superscript letters $\left({ }^{\mathrm{a}, \mathrm{b}}\right)$ within the same row tended to be different $(P=0.07)$ among control and longan-supplemented groups.

\section{Discussion}

The longan-supplemented in the present study responded with higher plasma concentrations of glucose and insulin indicating an enhanced metabolic status [24] of these animals compared with control ewes. This effect was not associated with a specific component in the longan fruit but to an increase in energy-yielding nutrients of treatment group [15]. The follicular results of this study suggested that supplementation of longan fruit increased the total DMI intake and total number of follicles, perhaps in response to the higher glucose and insulin concentrations. Similar finding was observed by Ying et al. [32] in Hu sheep who reported that the numbers of largesized follicles increased as feed intake increased. For this reason, a potential mechanism of nutritional effect on folliculogenesis was that supplementation increased the number of follicles escaping atresia [32]. In addition, a previous study suggested that high concentrations of glucose and metabolic hormones help the follicles to cope with the reduction in follicle-stimulating hormone (FSH) concentrations that accompanies follicular maturation, thereby helping them to escape atresia and allowing for an increase in ovulation rate [33]. In fact, glucose consumed by follicular cells can be used for energy production, cellular homeostasis, nuclear maturation, substrates for matrix production, as signals in four metabolic pathways: glycolysis, pentose phosphate pathway, hexosamine biosynthesis pathway, and the polyol pathway to maintain follicular growth and development [32,34]. Moreover, a previous review suggested that an increase insulin- mediated glucose uptake by granulosa and theca cells may be critical for the growth and development of follicles and the prevention of atresia, thereby increasing the pool of ovulatory follicles [36]. Thus, on reason for the inducible effect on the numbers of large-follicle and total follicle is likely to be that the 17-day period of dietary addition mainly influences the follicular development of growing follicles by modulating the intra-follicular insulin/glucose levels.

The efficiency of estrus synchronization and reproductive performance in our study were similar to that reported by Ozyurtlu et al. [21]. In the present study, we suggested that the dietary supplementation with longan fruit to ewes before estrus synchronization had a positive effect on follicular population. According to the chemical compositions of longan fruit, it is possible that the 17 days of dietary supplementation with longan fruit containing high gross energy arouse ovary ready to respond to the synchronization of estrus and subsequent reproduction in synchronized ewes, as demonstrated by increase in the efficiency of estrus synchronization (time to onset of estrus and duration of estrous period). This finding was consistent with a recent study in Malpura ewes supplemented with concentrate for 35 days covering two estrous cycles who reported that feed flushing affected the onset and duration of estrus in synchronized ewes [36]. At the beginning of CIDR insertion, mean numbers of total follicles had significantly greater in longan-supplemented ewes compared with control ewes. These data are supported by previous study, which demonstrated that the interval to estrus can already be predicted from the development of follicles at the time of CIDR insertion because the condition of ovaries did not change significantly during CIDR period [37].

\section{Conclusion}

The current study showed that the dietary supplementation with longan fruit to ewes before estrus synchronization had a positive effect on concentrations of glucose, insulin, $\mathrm{E}_{2}$, and total numbers of follicles. Moreover, the 17 days of dietary supplementation stimulate ovary (total follicles) ready to respond to the synchronization of estrus. Even though the dietary supplementation with longan fruit in ewes prior to the start of the estrus synchronization did not enhance estrous response and pregnancy rate, nutritional supplementation tended to improve time to onset of estrus and duration of estrous period.

\section{Acknowledgement}

This research project is supported by Faculty of Agriculture, Chiang Mai University (Targeted Research Initiatives). We would also thank Mrs. Sängdao Bänziger for their help in material preparation for nutritional supplementation in ewes.

\section{References}

[1] Zhou, Z., Zhou, B. Ren, L. and Meng, Q., "Effect of ensiled mulberry leaves and sun-dried mulberry fruit pomace on finishing steer growth performance, blood biochemical parameters, and carcass characteristics," PLOS ONE, 9(1). 85406-85412. Jan.2014. 
[2] Sanon, H.O., Kanwe, A.B., Millogo, A. and Ledin, I., "Chemical composition, digestibility, and voluntary feed intake of mango residues by sheep," Tropical Animal Health and Production, 45(2). 665-669. Feb.2013.

[3] Romero-Huelva, M., Ramos-Morales, E. and Molina-Alcaide, E., "Nutrient utilization, ruminal fermentation, microbial abundances, and milk yield and composition in dairy goats fed diets including tomato and cucumber waste fruits," Journal of Dairy Science, 95(10). 6015-6026. Agu.2012.

[4] Sruamsiri, S., The use of residues from longan production as cattle feed, The Thailand Research Fund (TRF), Bangkok, 2012, 1-77.

[5] Shdaifat, M.M., Al-Barakah, F.S., Kanan, A.Q. and Obeidat, B.S. "The effect of feeding agricultural by-products on performance of lactating Awassi ewes," Small Ruminant Research, 113(1). 11-14. Jun.2013.

[6] Hasachoo, N. and Kalaya, P., Competitiveness of local agriculture: the case of longan fruit trade between China and the north of Thailand, The Research Institute on Contemporary Southeast Asia (IRASEC) Publisher, Bangkok, 2013, 1-19.

[7] Choo, W.K., Longan production in Asia. Meetings and Publications Officer, FAO Regional Office for Asia and the Pacific, Bangkok, 2000, 1-51

[8] Jaisin, C., Pathaveerat, S. and Terdwongworakul, A., "Determining the size and location of longans in bunches by image processing technique," Maejo International Journal of Science and Technology, 7(3). 444-455. Nov.2013.

[9] Paull, R.E. and Duarte, O., Litchi and Longan, CAB International, Wallingford, 2011, 221-251.

[10] Subhadrabandhu, S., Lychee and longan cultivation in Thailand, Rumthai Publication, Bangkok, 1990, 1-40.

[11] Ohkura, S., Ichimaru, T. Itoh, F., Matsuyama, S. and Okamura, H., "Further evidence for the role of glucose as a metabolic regulator of hypothalamic gonadotropin-releasing hormone pulse generator activity in goats," Endocrinology, 145(7). 3239-3246. Mar.2004.

[12] Webb, R., Garnsworthy, P.C., Gong, J.-G. and Armstrong, D.G. "Control of follicular growth: Local interactions and nutritional influences," Journal of Animal Science, 82(1). 63-74. Nov.2004.

[13] Rondian, D., Freitas, V.J.F., Spinaci, M. and Galeati, G., "Effect of nutrition on plasma progesterone levels, metabolic parameters and small follicles development in unstimulated goats reared under constant photoperiod regimen," Reproduction in Domestic Animal, 40(6). 548-552. Dec.2005.

[14] Senory, W., Abdel-Raheem, S.M., Abd-Allah, M. Fahmy, S. Hassan, E.H. and Derar, R.I., "Effect of transient high-energy diets just after ovulation on ovarian performance and metabolic status in cyclic ewes," Small Ruminant Research, 109(2-3). 152-155. Jan.2013.

[15] Viñoles, C., Forsberg, M., Martin, G.B., Cajarville, C., Repetto, J. and Meikle, A., "Short-term nutrition supplementation of ewes in low body condition affects follicle development due to an increase in glucose and metabolic hormones," Reproduction, 129(3). 299309. Mar.2005.

[16] Downing, J.A., Joss, J., Connell, P. and Scaramuzzi, R.J., "Ovulation rate and the concentrations of gonadotrophic and metabolic hormones in ewes fed lupin grain," Journal of Reproduction and Fertility, 103(1). 137-145. Jan.1995.

[17] Somchit, A., Campbell, B.K., Khalid, M., Kendall, N.R. and Scaramuzzi, R.J., "The effect of short-term nutritional supplementation of ewes with lupin grain (Lupinus luteus), during the luteal phase of the estrous cycle on the number of ovarian follicles and the concentrations of hormones and glucose in plasma and follicular fluid," Theriogenology, 68(7). 1037-1046. Sep.2007.

[18] Moonmanee, T., Navanukraw, C., Thammasiri, J., Aiumlami, S. and Kamollirt, C., "Evaluation of ovarian follicular health with the markers of endothelial and granulosa cells," Chiang Mai University Journal of Natural Sciences, 11(1). 461-467. Aug.2012a.

[19] Moonmanee, T, Navanukraw, C., Aiumlamai, S., Jarukamjorn, K., Thammasiri, J. and Redmer, D.A., "Quantitative vascularity of antral follicle in Bos indicus using Factor VIII immunolocalization," Livestock Science, 150(1-3). 128-134. Dec.2012b.

[20] Grasser, L.A., Fadel, J.G., Garnett, I. and Depeters, E., "Quantity and economic importance of 9 selected byproducts used in California dairy rations," Journal of Dairy Science, 78(4). 962-971. Apr.1995.
[21] Ozyurtlu, N., Kucukaslan, I. and Cetin, Y., "Characterization of oestrous induction response, oestrous duration, fecundity and fertility in Awassi ewes during the non-breeding season utilizing both CIDR and intravaginal sponge treatments," Reproduction in Domestic Animal, 45(3). 464-467. Jun.2010.

[22] AOAC., Official Method of Analysis. $16^{\text {th }}$ ed Association of Official Analysis Chemists, Gaithergurg, Maryland, 1998.

[23] Mahgoub, O., Kadim, I.T., Johnson, E.H., Srikandakumar, A., AlSaqri, N.M. Al-Abri, A.S. and Ritchie, A., "The use of a concentrate containing Meskit (Prosopis juliflora) pods and date palm by-products to replace commercial concentrate in diets of Omani sheep," Animal Feed Science and Technology, 120(1). 3341. Jun.2005.

[24] Hashem, N.M. and EI-Zarkouny, S.Z., "Effect of short-term supplementation with rumen-protected fat during the late luteal phase on reproduction and metabolism of ewes," Journal of Animal Physiology and Animal Nutrition, 98(1). 65-71. Feb.2014.

[25] Hashem, N.M. and Sallam, S.M.A., "Sexual and ovarian activity of crossbred ewe fed different types of roughage during seasonal anestrus," Small Ruminant Research, 107(2-3). 136-140. Oct.2012.

[26] El-Shahat, K.H. and Abo-Elmaaty, A.M., "The effect of dietary supplementation with calcium salts of long chain fatty acids and/or l-carnitine on ovarian activity of Rahmani ewes," Animal Reproduction Science, 117(1-2). 78-82. May.2010.

[27] Aekplakorn, W., Abbott-Klafter, J., Premgamone, A., Dhanamun, B., Caikittiporn, C., Chongsuvivatwong, V., Suwanprapisa, T., Chaipornsupaisan, W., Tiptaradol, S. and Lim, S.S., "Prevalence and management of diabetes and associated risk factors by regions of Thailand," Diabetes Care, 30(8). 2007-2012. Apr.2007.

[28] Brown, J., Walker, S. and Steinman, K., Endocrine manual for reproductive assessment of domestic and non-domestic species, Smithsonian's National Zoological Park, Conservation and Research Center, Virginia, 2005, 1-69.

[29] Steel, R.G.D., Torrie, J.H. and Dickey, D., Principles and procedures of statistics: a biometrical approach, McGraw-Hill Press, New York, 1997, 1-256.

[30] Navanukraw, C., Reynolds, L.P., Kirsch, J.D., Grazul-Bilska, A.T., Redmer, D.A. and Fricke, P.M., "A modified presynchronization protocol improves fertility to timed artificial insemination in lactating dairy cows," Journal of Dairy Science, 87(5). 1551-1557. May.2004.

[31] Lima, F.S., Risco, C.A., Thatcher, M.J., Benzaquen, M.E., Archbald, L.F., Santos, J.E.P. and Thatcher, W.W., "Comparison of reproductive performance in lactating dairy cows bred by natural service or timed artificial insemination," Journal of Dairy Science, 92(11). 5456-5466. Nov.2009.

[32] Ying, S., Wang, Z., Wang, C., Nie, H., He, D., Jia, R., Wu, Y., Wan, Y., Zhou, Z., Yan, Y., Zhang, Y. and Wang, F., "Effect of different levels of short-term feed intake on folliculogenesis and follicular fluid and plasma concentrations of lactate dehydrogenase, glucose, and hormones in Hu sheep during the luteal phase," Reproduction, 142(5). 699-710. Nov.2011.

[33] Viñoles, C., Paganoni, B., Glover, K.M.M., Milton, J.T.B., Blache, D., Blackberry, M.A. and Martin, G.B., "The use of a 'first-wave' model to study the effect of nutrition on ovarian follicular dynamics and ovulation rate in the sheep," Reproduction, 140(6). 865-874. Dec.2010

[34] Sutton-McDowall, M.L., Gilchrist, R.B. and Thompson, J.G., "The pivotal role of glucose metabolism in determining oocyte developmental competence," Reproduction, 139(4). 685-695. Apr.2010.

[35] Naqvi, S.M.K., Sejian, V. and Karim, S.A., "Effect of feed flushing during summer season on growth, reproductive performance and blood metabolites in Malpura ewes under semiarid topical environment," Tropical Animal Health and Production, 45(1). 143-148. Jun.2013.

[36] Scaramuzzi, R.J., Campbell, B.K., Downing, J.A., Kendall, N.R., Khalid, M., Munoz-Gutiérrez, M. and Somchit, A., "A review of the effects of supplementary nutrition in the ewe on the concentrations of reproductive and metabolic hormones and the mechanisms that regulate folliculogenesis and ovulation rate," Reproduction, Nutrition, and Development, 46(1). 339-354. Dec.2006.

[37] Dolezel, R., K. Karlberg, E. Ropstad, and K. Landsverk, "Ultrasound observation of ovarian structures in cows during intravaginal progesterone device application and in the following sexual cycle," Acta Veterinaria Brno, 62(3). 179-185. May.1993. 